\title{
Electrochemical determination of hydrogen peroxide using $o$-dianisidine as substrate and hemoglobin as catalyst
}

\author{
WEI SUN*, HONG JIANG and KUI JIAO \\ College of Chemistry and Molecular Engineering, Qingdao University of Science and Technology, \\ Qingdao 266042, PR China \\ e-mail: sunwei_1975@public.qd.sd.cn
}

MS received 10 November 2004; revised 21 March 2005

\begin{abstract}
A new electrochemical method for the determination of microamounts of hydrogen peroxide utilizing $o$-dianisidine (ODA) as substrate and hemoglobin $(\mathrm{Hb})$ as catalyst is described in this paper. Hb can be used as mimetic peroxidase and it can catalyse the reduction of hydrogen peroxide with the subsequent oxidation of ODA. The oxidative reaction product is an azo compound, which is an electroactive substance and has a sensitive second-order derivative polarographic reductive peak at the potential of $-0 \cdot 58 \mathrm{~V}$ (vs. $\mathrm{SCE}$ ) in $\mathrm{pH} 8.0$ Britton-Robinson (B-R) buffer solution. The conditions of Hb-catalytic reaction and polarographic detection of the reaction product were carefully studied. By using this polarographic peak and under optimal conditions, the calibration curve for the $\mathrm{H}_{2} \mathrm{O}_{2}$ was constructed in the linear range of $2.0 \times 10^{-7}$ $\sim 1.0 \times 10^{-4} \mathrm{~mol} / \mathrm{l}$ with the detection limit of $5 \cdot 0 \times 10^{-8} \mathrm{~mol} / \mathrm{l}$. This method can also be used to the determination of $\mathrm{Hb}$ content in the range of $2 \cdot 0 \times 10^{-9} \sim 3.0 \times 10^{-7} \mathrm{~mol} / \mathrm{l}$ with a detection limit of $1.0 \times 10^{-9} \mathrm{~mol} / \mathrm{l}$. The proposed method was further applied to the determination of the content of $\mathrm{H}_{2} \mathrm{O}_{2}$ in fresh rainwater with satisfactory results. The catalytic reaction mechanism and the electrode reductive process of the reaction product were carefully studied.
\end{abstract}

Keywords. Hemoglobin; hydrogen peroxide; $o$-dianisidine, polarography.

\section{Introduction}

Hemoglobin $(\mathrm{Hb})$ is an important respiratory protein in red cells of human blood, which is used as the carrier of oxygen. Its concentration in blood is associated with some clinical diseases such as heart disease, anemia, etc. Similarly, hydrogen peroxide plays an important role in the clinical and biological fields. The oxidation of many biological substances in body fluids produces a certain amount of hydrogen peroxide. ${ }^{1,2}$ Further, the content of hydrogen peroxide in the environment is important because it is a key species in the reaction of the troposphere. ${ }^{3}$ So the sensitive determination of both $\mathrm{Hb}$ and $\mathrm{H}_{2} \mathrm{O}_{2}$ has aroused great interest in analytical chemistry.

Until now many methods have been proposed for the analysis of $\mathrm{H}_{2} \mathrm{O}_{2}$ or $\mathrm{Hb}$. For the determination of $\mathrm{H}_{2} \mathrm{O}_{2}$, methods such as electroanalysis, ${ }^{4}$ spectrophotometry, ${ }^{5}$ fluorescence ${ }^{6}$ etc. have been established. For the determination of $\mathrm{Hb}$, the commonly used method is spectrophotometry. ${ }^{7-9}$ However, the spectrophoto-

\footnotetext{
*For correspondence
}

metric detection is less sensitive due to the greater influence of hemolysis and turbidity of biological sample. Electrochemical analysis has inherent advantages over spectrophotometry, such as lower detection limit and wide dynamic range. The determination of $\mathrm{Hb}$ with electrochemical methods has been reported, ${ }^{10,11}$ but most of them focused on the chemically modified electrode with some redox mediators such as methylene blue, which can enhance the charge transfer rate of $\mathrm{Hb}$ on the electrode surface. But those methods are handicapped by the difficult preparation and poor reproducibility of modified electrode.

$\mathrm{Hb}$ consists of four polypeptide subunits and an ironporphyrin heme as the active centre. So it has the inherent reactivity as a peroxidase, which can catalyse the reduction of hydrogen peroxide and the oxidation of a hydrogen donor substrate at the same time. Based on this principle, $\mathrm{Hb}$ has been used as the mimetic enzyme of peroxidase. Zhang et $a l^{12}$ reported a new stopped flow spectrophotometric method for the determination of $\mathrm{Hb}$, based on its enzymatic activity using $o$-phenylenediamine as substrate. Wang ${ }^{13}$ applied $\mathrm{Hb}$ as the peroxidase substitute in the catalytic oxida- 
tion of $p$-cresol by $\mathrm{H}_{2} \mathrm{O}_{2}$ and further established a sensitive spectrofluorimetric method for the determination of trace $\mathrm{H}_{2} \mathrm{O}_{2}$.

In this paper, a new electrochemical method for the determination of trace amount of $\mathrm{H}_{2} \mathrm{O}_{2}$ and $\mathrm{Hb}$ using $o$-dianisidine(ODA) as substrate is reported for the first time. ODA has been used as the chromogen substrate for HRP and HRP-based enzyme immunoassay. ${ }^{14,15}$ So in this paper ODA was selected as the electrochemical substrate of $\mathrm{Hb}$ catalytic reaction for the determination of $\mathrm{H}_{2} \mathrm{O}_{2}$. The conditions for $\mathrm{Hb}^{-} \mathrm{H}_{2} \mathrm{O}_{2-}$ ODA reaction system were carefully optimized and the electrochemical behaviour of oxidative reaction product was investigated. Based on the electrochemical reduction of the reaction product on the mercury electrode, a sensitive electrochemical method for analysis of $\mathrm{H}_{2} \mathrm{O}_{2}$ and $\mathrm{Hb}$ is established, which is successfully attempted to determine $\mathrm{H}_{2} \mathrm{O}_{2}$ content in fresh rainwater with satisfactory results.

\section{Experimental}

\subsection{Apparatus}

A model JP-303 polarographic analyzer (Chengdu Instrument Factory, China) was used for all polarographic detections with the traditional three electrodes system involving a dropping mercury as working electrode, a platinum wire auxiliary electrode and an saturated calomel reference electrode (SCE). All the cyclic voltammetric experiments were carried out using a DS-2004 electrochemical analyser (Shandong Dongsheng Electronic Instrument, China) with a DS991 static mercury drop electrode (Shandong Dongsheng Electronic Instrument, China) as working electrode, a saturated calomel reference electrode (SCE) and a platinum wire auxiliary electrode. The UV-Vis absorption spectrum was measured on a Cary 50 probe UV-Vis spectrophotometer (Australia Varian Company). A thermostat bath was used to control the reaction temperature.

\subsection{Materials}

Hemoglobin (bovine, $\mathrm{Hb}$, Biochemical grade) was purchased from Tianjin Chuanbei Bio-product Company with the molecular weight of $64500,1.0 \times 10^{-4} \mathrm{~mol} / \mathrm{l}$ stock solution was prepared and stored at $4^{\circ} \mathrm{C}$. The working solution of $\mathrm{Hb}$ was prepared daily by diluting the stock solution to the suitable concentration. $1.0 \times 10^{-2} \mathrm{~mol} / \mathrm{l} o$-diansidine (ODA, Sigma) solution in methanol was prepared and stored in the dark. $\mathrm{H}_{2} \mathrm{O}_{2}$ solution was prepared by appropriate dilution of commercial $30 \% \mathrm{H}_{2} \mathrm{O}_{2}$ with water and standardized by titration with $\mathrm{KMnO}_{4} .0 .2 \mathrm{~mol} / \mathrm{l}$ BrittonRobinson (B-R) buffer solution ( $\mathrm{pH}$ 8.0) and $0.1 \mathrm{~mol} / \mathrm{l} \quad \mathrm{KH}_{2} \mathrm{PO}_{4}-\mathrm{Na}_{2} \mathrm{HPO}_{4}$ buffer solution $(\mathrm{pH}$ 6.6) were prepared respectively to control the $\mathrm{pH}$ of reaction solution. All chemicals used are of analytical reagent grade and doubly distilled water was used for preparing the solutions.

\subsection{Procedure}

In a $10 \mathrm{ml}$ colorimetric tube, $0.5 \mathrm{ml} \mathrm{pH} 6.6 \mathrm{KH}_{2} \mathrm{PO}_{4-}$ $\mathrm{Na}_{2} \mathrm{HPO}_{4}$ buffer solution and $2.0 \mathrm{ml}$ of $1.0 \times$ $10^{-2} \mathrm{~mol} / \mathrm{l}$ ODA was mixed with a suitable amount of $\mathrm{H}_{2} \mathrm{O}_{2}$ and $\mathrm{Hb}$ solutions in sequence, then diluted to $10 \mathrm{ml}$ with methanol. After reaction at $50^{\circ} \mathrm{C}$ for $50 \mathrm{~min}$, the reaction solution was cooled with icewater to stop the catalytic reaction. Then $5.0 \mathrm{ml}$ of reaction solution was transferred to another $10 \mathrm{ml}$ colorimetric tube and $1.5 \mathrm{ml} \mathrm{pH} 8.0 \mathrm{~B}-\mathrm{R}$ buffer solution was added, diluted to the scale and shaken to mix homogenously. The second order derivative linearsweep polarographic peak of the reaction product was recorded and the reductive peak current at $-0.58 \mathrm{~V}$ (vs. SCE) was measured.

\section{Results and discussion}

\subsection{UV-Vis absorption spectra}

Figure 1 shows the UV-Vis absorption spectra of $\mathrm{Hb}-\mathrm{H}_{2} \mathrm{O}_{2}$-ODA catalytic system in the wavelength range from 300 to $700 \mathrm{~nm}$. Curve 1 is the mixture of ODA with $\mathrm{H}_{2} \mathrm{O}_{2}$ and it shows no absorbance. After adding the different amount of $\mathrm{Hb}$ solution and reacted at $50^{\circ} \mathrm{C}$ for $50 \mathrm{~min}$, a new absorption peak appears at $438 \mathrm{~nm}$ and increases with the addition of the amount of $\mathrm{Hb}$, which indicated a new reaction product was formed due to the $\mathrm{Hb}$ catalysed $\mathrm{H}_{2} \mathrm{O}_{2}$ oxidation of ODA.

\subsection{Typical second-order derivative linear sweep polarogram of $\mathrm{Hb}-\mathrm{H}_{2} \mathrm{O}_{2}$-ODA catalytic system}

As shown in figure 2, the typical second order derivative linear sweep polarogram of $\mathrm{Hb}-\mathrm{H}_{2} \mathrm{O}_{2}$-ODA catalytic system was recorded. Curve 1 is the polarogram of buffer solution, which has no polarographic peak. Curve 2 is the polarogram of ODA + Hb solution, 
it has a small blank wave, which is due to the oxidation of ODA by air. Curve 3 is the polarogram of ODA + $\mathrm{H}_{2} \mathrm{O}_{2}$ solution, which is similar as curve 2 and is due to the slowly oxidation of ODA by $\mathrm{H}_{2} \mathrm{O}_{2}$. Curve 4 is the mixture of ODA $+\mathrm{Hb}+\mathrm{H}_{2} \mathrm{O}_{2}$, which has a welldefined polarographic reductive peak at the potential of $-0.58 \mathrm{~V}$ (vs SCE). Due to the addition of $\mathrm{H}_{2} \mathrm{O}_{2}$ and $\mathrm{Hb}$, the Hb-catalytical oxidation reaction is speeded up and a new electroactive reaction product is formed. The more the $\mathrm{H}_{2} \mathrm{O}_{2}$ or $\mathrm{Hb}$ added, the more the oxidation product is generated and the higher the peak current is got. The peak current is in proportion to the concentration of $\mathrm{H}_{2} \mathrm{O}_{2}$ and $\mathrm{Hb}$, so this method can be applied to the determination of $\mathrm{H}_{2} \mathrm{O}_{2}$ or $\mathrm{Hb}$ content in real samples.

\subsection{Electrochemical behaviour of $\mathrm{Hb}$ catalytic reaction product}

In our previous paper, ${ }^{16}$ the oxidative reaction of horseradish peroxidase(HRP) catalysed $\mathrm{H}_{2} \mathrm{O}_{2}$ with ODA have been studied and reported. Because of the similar catalytical function of HRP with $\mathrm{Hb}$, so the reaction of ODA and $\mathrm{H}_{2} \mathrm{O}_{2}$ with $\mathrm{Hb}$ can also produce a new azo-compound though the reaction scheme shown in figure 3 . This bisazobiphenyl product is produced from the condensation of two molecules of the $o$-dianiside quinonediimine, which can easily be reduced on the mercury electrode. Thus the catalytic reaction can be monitored by polarographic detection of the reductive current, which was generated

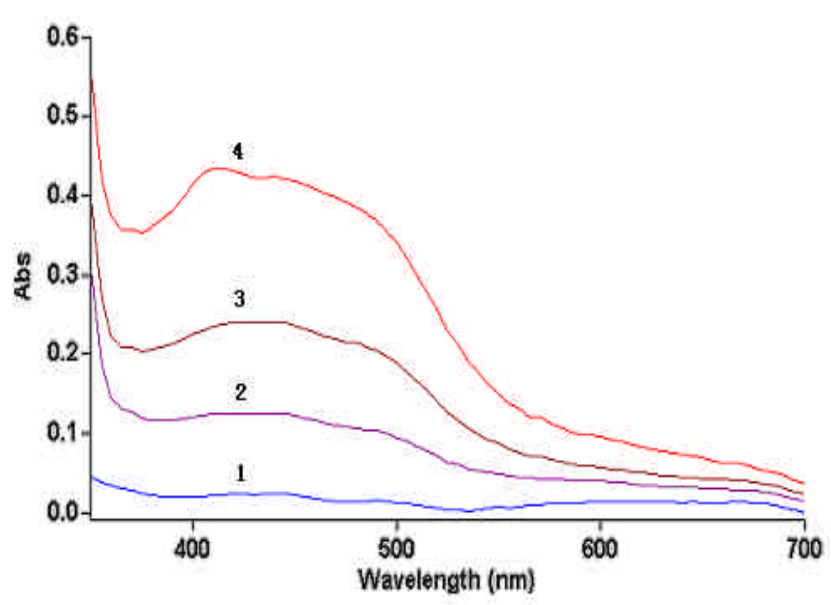

Figure 1. UV-Vis absorption spectra of $\mathrm{Hb}-\mathrm{H}_{2} \mathrm{O}_{2}-\mathrm{ODA}$ catalytic system in the absence and present of different amount of $\mathrm{Hb}$. (1) $1.0 \times 10^{-3} \mathrm{~mol} / \mathrm{l} \mathrm{ODA}+2.0 \times$ $10^{-3} \mathrm{~mol} / \mathrm{l} \mathrm{H} \mathrm{H}_{2}$; (2) (1) $+1.0 \times 10^{-5} \mathrm{~mol} / \mathrm{l} \mathrm{Hb}$; (3) (2) $+2.0 \times 10^{-5} \mathrm{~mol} / \mathrm{l} \mathrm{Hb}$; (4) (3)+5.0 $\times 10^{-5} \mathrm{~mol} / \mathrm{l} \mathrm{Hb}$. by reductive reaction of the azo group of the product. So the electrochemical properties of this bisazo product were carefully studied.

For the $\mathrm{Hb}$ catalytical reaction solution and under the selected conditions, the cyclic voltammogram of this bisazo product was recorded and is shown in figure 4. It can be seen that the product had a pair of redox peaks with the anodic peak potential $\left(E_{p a}\right)$ as $0.44 \mathrm{~V}$ and the cathodic peak potential $\left(E_{p c}\right)$ as $-0.59 \mathrm{~V}$. So the apparent formal potential $\left(E^{0}\right)$ has been calculated as $-0.515 \mathrm{~V}$, since $E^{0}$ is the average of $E_{p a}$ and $E_{p c}$. The peak potential separation $\Delta E_{p}=$ $\left|E_{p a}-E_{p c}\right|$ is calculated as $0.15 \mathrm{~V}$ with the peak current of $I_{p a} / I_{p c} \neq 1$, which indicates that the electrode process of the oxidative product on the mercury electrode was quasi-reversible. The reductive peak currents increase with the scanning rate in the range of $100 \sim 800 \mathrm{mV} / \mathrm{s}$. The plot of peak current with square root of the scanning rate is not linear but an upward curve, which indicates that the azo product can be absorbed on the surface of mercury electrode. The peak current also increases with the increasing of the static period of mercury drop. In multiple sweep cyclic voltammograms the peak current decreases gradually with increasing scan times. All this electrochemical experiments results show that the reaction product can be strongly absorbed on to the mercury electrode. The plot of the peak potential against the $\mathrm{pH}$ of buffer is a straight line with a slope of -0.058 in the $\mathrm{pH}$ range of $6.0 \sim 10.0$, According to the equation, $-0 \cdot 059 x / n=-0 \cdot 058$, where

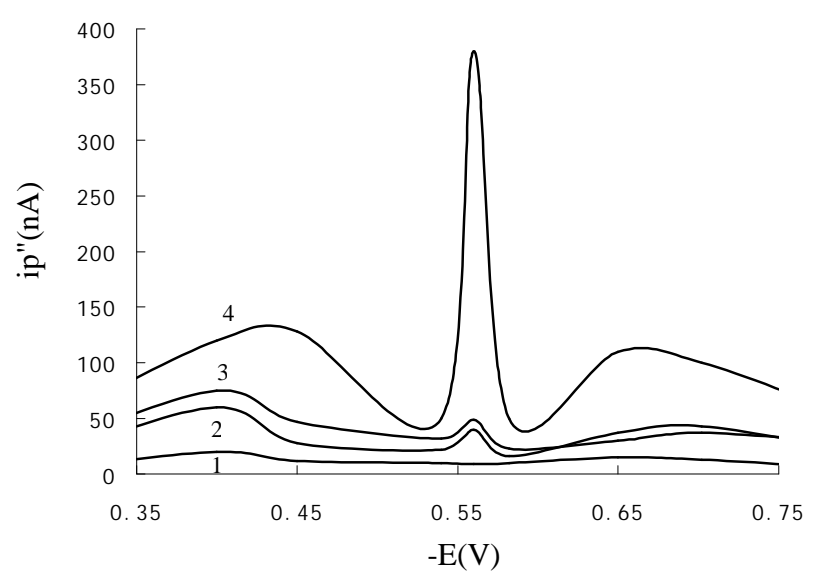

Figure 2. The linear sweep second order derivative polarogram of $\mathrm{Hb}-\mathrm{H}_{2} \mathrm{O}_{2}-\mathrm{ODA}$ catalytic system. (1) 0.05 $\mathrm{mol} / \mathrm{l} \mathrm{KH}_{2} \mathrm{PO}_{4}-\mathrm{Na}_{2} \mathrm{HPO}_{4}$ buffer solution (pH 6.6); (2) (1) $+1.0 \times 10^{-3} \mathrm{~mol} / 1$ ODA $+1.0 \times 10^{-7} \mathrm{~mol} / 1 \mathrm{Hb}$; (3) (1) $+1.0 \times 10^{-3} \mathrm{~mol} / \mathrm{l} \mathrm{ODA}+1.5 \times 10^{-5} \mathrm{~mol} / 1 \mathrm{H}_{2} \mathrm{O}_{2}$; (4) (2) + $1.5 \times 10^{-5} \mathrm{~mol} / 1 \mathrm{H}_{2} \mathrm{O}_{2}$. 


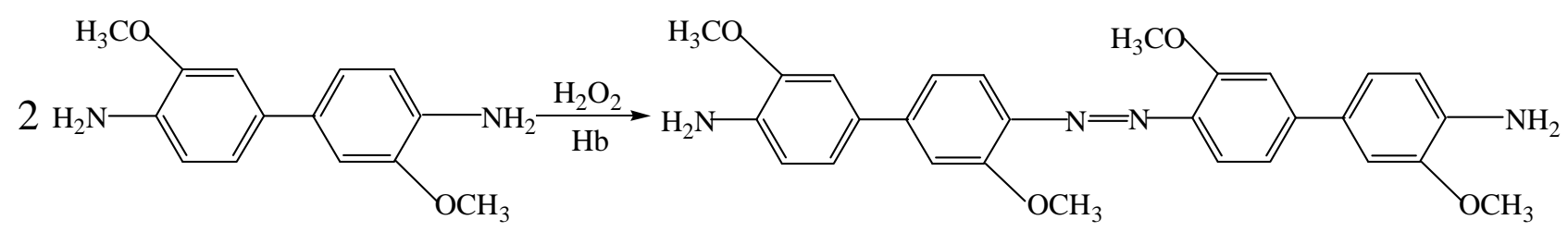

Figure 3. Catalytic oxidation reaction scheme.

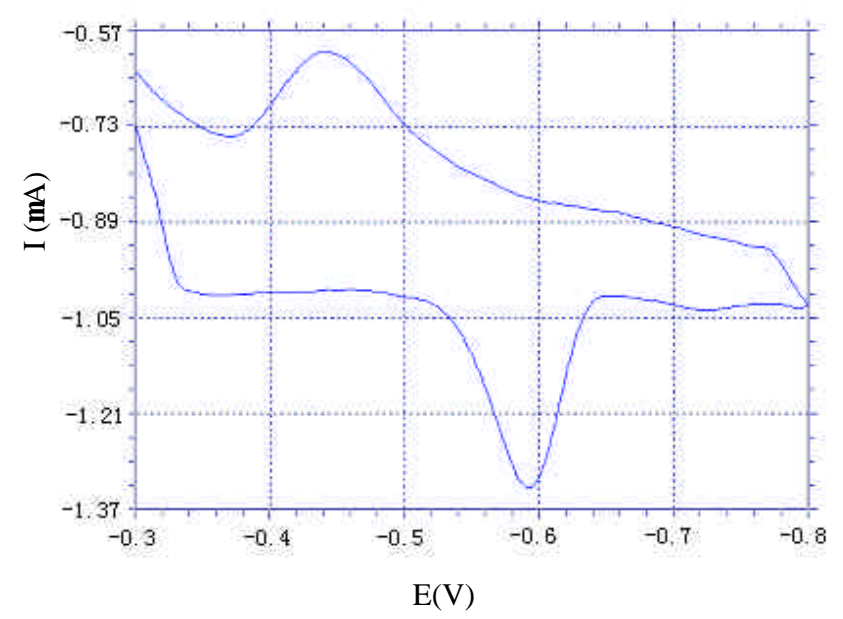

Figure 4. Cyclic voltammogram of the oxidation product under selected conditions with the scan rate as $300 \mathrm{mV} / \mathrm{s}$.

$n$ is the electron transfer number and $x$ is the hydrogen ion number participating in the reaction, so $x=2$ and $n=2$. From the above experimental results, the azo product appears to undergo two-electron adsorptive quasi-reversible reduction on the $\mathrm{Hg}$ electrode as shown in figure 5 .

\subsection{Optimization of the conditions of $\mathrm{Hb}$ catalytic reaction and polarographic detection}

3.4a Effect of $p H$ and buffers: The kind of the buffer solution and $\mathrm{pH}$ of the reaction buffer greatly affects the activity of $\mathrm{Hb}$. Differential buffer solution such as phosphate, $\mathrm{B}-\mathrm{R}$, carbonate, etc. were tested and the results show that in $\mathrm{KH}_{2} \mathrm{PO}_{4^{-}}$ $\mathrm{Na}_{2} \mathrm{HPO}_{4}$ buffer solution the activity of $\mathrm{Hb}$ is the highest. Figure 6 shows the dependence of $\mathrm{pH}$ with peak currents in the range from $5 \cdot 0$ to $7 \cdot 5$. The peak current reaches maximum in the $\mathrm{pH}$ range of $6 \cdot 2 \sim$ $6 \cdot 6$, so $\mathrm{pH} 6.6$ was recommended for use in our work and the addition of $0.5 \mathrm{ml}$ of $0.1 \mathrm{~mol} / \mathrm{l}$ phosphate buffer solution in $10 \mathrm{ml}$ final solution is chosen. 3.4b Reaction time and temperature: Under the above conditions, the influence of temperature on the $\mathrm{Hb}$ catalytic reaction was examined with the reaction temperature in the range from 20 to $70^{\circ} \mathrm{C}$ and the results are shown in figure 7 . When the temperature is lower than $50^{\circ} \mathrm{C}$, the peak current of the catalytic product increases with the increase of temperature and it reaches a maximum at $50^{\circ} \mathrm{C}$; when the temperature exceeds $50^{\circ} \mathrm{C}$, the peak current decreases correspondingly, which may be due to the denaturing of protein at high temperature. Therefore, a reaction temperature of $50^{\circ} \mathrm{C}$ is suggested for the catalytic reaction. At this temperature, the peak current reaches the maximum for $50 \mathrm{~min}$ and remains constant for at least $3 \mathrm{~h}$.

3.4c Optimal concentration of the substrate: ODA is an excellent spectrophotometric and electrochemical substrate in $\mathrm{HRP}-\mathrm{H}_{2} \mathrm{O}_{2}$ catalytic system, so it was chosen as the substrate for $\mathrm{Hb}$. Results show that the peak current increases with the increasing of the concentration of ODA up to $2.0 \times 10^{-3} \mathrm{~mol} / \mathrm{l}$ and then decreases thereafter. So a concentration of ODA is chosen as $2 \cdot 0 \times 10^{-3} \mathrm{~mol} / \mathrm{l}$.

\section{4d Optimal conditions for polarographic detec-} tion: Polarographic behaviour of the Hb-catalytic reaction product is greatly influenced by the acidity of the supporting electrolyte. After the catalytic reaction, the effect of the $\mathrm{pH}$ of the supporting electrolyte on the electrochemical response of the enzymatic product was checked in the $\mathrm{pH}$ range from 6.0 to 10.0. The results show that in $\mathrm{pH} 8.0 \mathrm{~B}-\mathrm{R}$ buffer supporting electrolyte solution, peak current reaches the maximum and decreases with further increase of the buffer $\mathrm{pH}$ (Figure 8). Under the selected conditions, the polarographic peak current remains stable for about $2 \mathrm{~h}$.

The optimal instrumental conditions for the detection were selected as follows: initial potential: $-0.40 \mathrm{~V}$; mercury drop standing time: $13 \mathrm{~s}$ and potential scanning rate: $1000 \mathrm{mV} / \mathrm{s}$. 
<smiles>COc1cc(-c2ccc(N=Nc3ccc(-c4ccc(N)c(OC)c4)cc3OC)c(OC)c2)ccc1N</smiles><smiles>COc1cc(-c2ccc(NNc3ccc(-c4ccc(N)c(OC)c4)cc3OC)c(OC)c2)ccc1N</smiles>

Figure 5. Electro-reduction scheme.

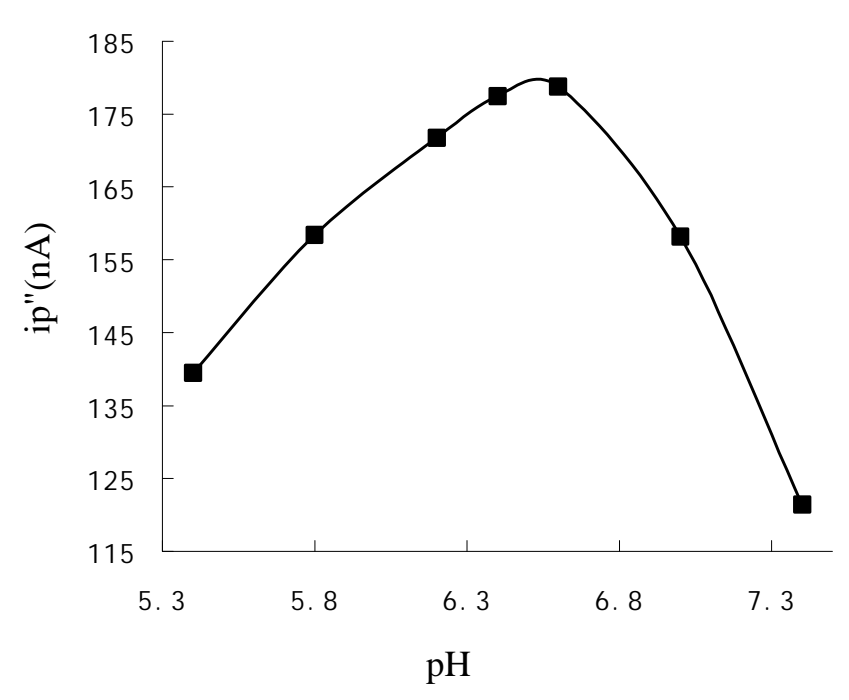

Figure 6. Influence of $\mathrm{pH}$ on the catalytic reaction. Concentrations of ODA, $\mathrm{H}_{2} \mathrm{O}_{2}$ and $\mathrm{Hb}$ are $1.0 \times 10^{-3}$ $\mathrm{mol} / \mathrm{l}, 4.0 \times 10^{-6} \mathrm{~mol} / \mathrm{l}, 1.0 \times 10^{-7} \mathrm{~mol} / \mathrm{l}$. Phosphate buffer solutions of different $\mathrm{pH}$ values are used.

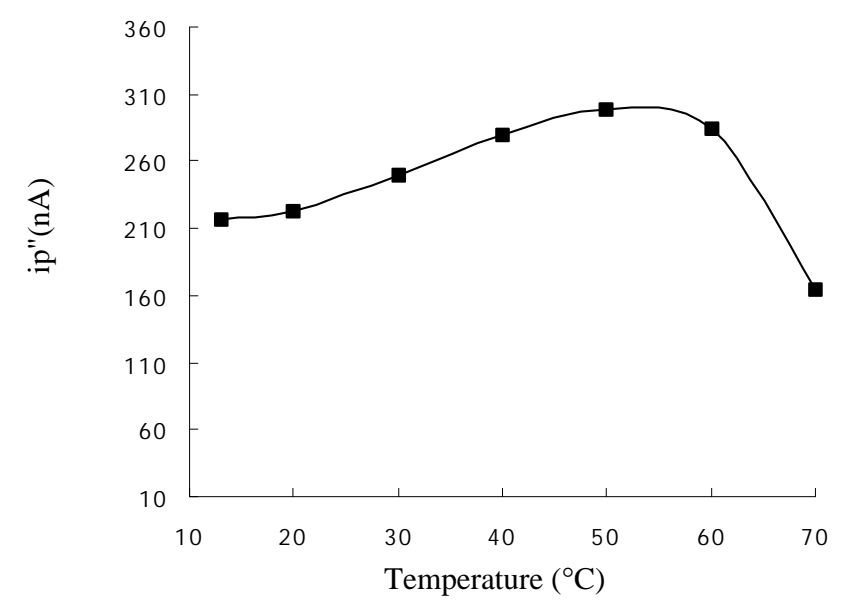

Figure 7. The influence of temperature on catalytic reaction. Concentrations of ODA, $\mathrm{H}_{2} \mathrm{O}_{2}$ and $\mathrm{Hb}$ are $1.0 \times$ $10^{-3} \mathrm{~mol} / \mathrm{l}, 1.0 \times 10^{-5} \mathrm{~mol} / \mathrm{l}, 1.0 \times 10^{-7} \mathrm{~mol} / 1$ with $\mathrm{pH} 6.6$ phosphate buffer solution.

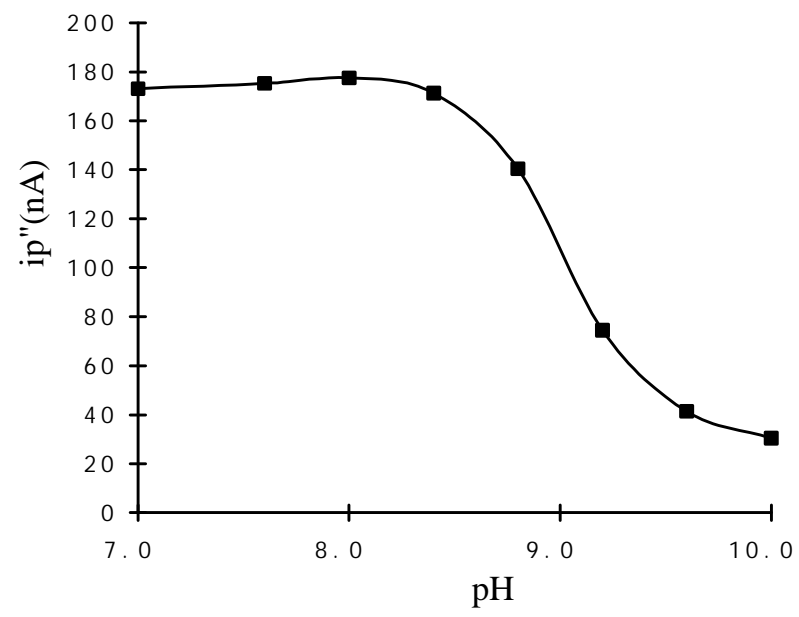

Figure 8. The influence of $\mathrm{pH}$ on the peak current. Concentrations of ODA, $\mathrm{H}_{2} \mathrm{O}_{2}$ and $\mathrm{Hb}$ are $1.0 \times 10^{-3}$ $\mathrm{mol} / \mathrm{l}, 4.0 \times 10^{-6} \mathrm{~mol} / 1,1.0 \times 10^{-7} \mathrm{~mol} / 1$.

\subsection{Analytical application}

3.5a Quantitative determination of $\mathrm{H}_{2} \mathrm{O}_{2}$ : Under optimal reaction and detection conditions, the calibration curve of peak current versus the concentration of $\mathrm{H}_{2} \mathrm{O}_{2}$ was constructed with $2.0 \times 10^{-3} \mathrm{~mol} / \mathrm{l}$ ODA and $1.0 \times 10^{-7} \mathrm{~mol} / \mathrm{l} \mathrm{Hb}$. Good linearity can be found as follows: (1) in the range of $2.0 \times 10^{-7}$ to $1.0 \times$ $10^{-5} \mathrm{~mol} / \mathrm{l}$ with the linear regression equation as $i p^{\prime \prime}$ $(\mathrm{nA})=40 \cdot 30+29 \cdot 30 \mathrm{C}(\mu \mathrm{mol} / \mathrm{l}),(\gamma=0.998, n=13)$; (2) in the range of $1.0 \times 10^{-5}$ to $1.0 \times 10^{-4} \mathrm{~mol} / \mathrm{l}$ with the linear regression equation as $i p^{\prime \prime}(\mathrm{nA})=248.08+$ $8.47 \mathrm{C}(\mu \mathrm{mol} / \mathrm{l}),(\gamma=0.997, n=6)$, where $i p^{\prime \prime}(\mathrm{nA})$ is the reductive peak current and $C$ is the concentration of $\mathrm{H}_{2} \mathrm{O}_{2}$. The relative standard deviation for 11 parallel determinations of $1.0 \times 10^{-7} \mathrm{~mol} / 1 \mathrm{H}_{2} \mathrm{O}_{2}$ was $3.01 \%$ and the detection limit was $5.0 \times 10^{-8} \mathrm{~mol} / \mathrm{l}$.

3.5b Sample determinations of $\mathrm{H}_{2} \mathrm{O}_{2}$ and recovery test: Under the recommended conditions, the proposed method was applied to determination of the 
Table 1. Analytical results of the content of $\mathrm{H}_{2} \mathrm{O}_{2}$ in fresh rainwater.

\begin{tabular}{|c|c|c|c|c|c|c|c|c|}
\hline \multirow{2}{*}{$\begin{array}{l}\text { Sample } \\
1\end{array}$} & \multicolumn{3}{|c|}{$\begin{array}{c}\text { Found } \\
\left(\times 10^{-5} \mathrm{~mol} / \mathrm{l}\right)\end{array}$} & \multirow{2}{*}{$\begin{array}{c}\begin{array}{c}\text { Average } \\
\left(\times 10^{-5} \mathrm{~mol} / \mathrm{l}\right)\end{array} \\
6.86\end{array}$} & \multirow{2}{*}{$\frac{\operatorname{RSD}(\%)}{3.91}$} & \multirow{2}{*}{$\begin{array}{c}\begin{array}{c}\text { Added } \\
\left(\times 10^{-5} \mathrm{~mol} / \mathrm{l}\right)\end{array} \\
10 \cdot 00\end{array}$} & \multirow{2}{*}{$\begin{array}{c}\begin{array}{c}\text { Detected } \\
\left(\times 10^{-5} \mathrm{~mol} / \mathrm{l}\right)\end{array} \\
16.78\end{array}$} & \multirow{2}{*}{$\begin{array}{c}\begin{array}{c}\text { Recovery } \\
(\%)\end{array} \\
99.18\end{array}$} \\
\hline & 6.59 & $6 \cdot 72$ & $7 \cdot 17$ & & & & & \\
\hline & $6 \cdot 66$ & $7 \cdot 22$ & $6 \cdot 81$ & & & & & \\
\hline \multirow[t]{2}{*}{2} & $3 \cdot 28$ & $3 \cdot 36$ & $3 \cdot 59$ & $3 \cdot 43$ & $4 \cdot 01$ & $10 \cdot 00$ & $13 \cdot 78$ & $103 \cdot 52$ \\
\hline & $3 \cdot 33$ & $3 \cdot 61$ & $3 \cdot 41$ & & & & & \\
\hline \multirow[t]{2}{*}{3} & $5 \cdot 44$ & $5 \cdot 36$ & $5 \cdot 87$ & $5 \cdot 57$ & $3 \cdot 35$ & $10 \cdot 00$ & $15 \cdot 45$ & $98 \cdot 79$ \\
\hline & $5 \cdot 47$ & $5 \cdot 61$ & $5 \cdot 69$ & & & & & \\
\hline
\end{tabular}

content of $\mathrm{H}_{2} \mathrm{O}_{2}$ in fresh rainwater. The analytical results are listed in table 1 . The recovery tests show that this method is practicable and reliable.

3.5c Calibration curve for $\mathrm{Hb}$ assay: In this system $\mathrm{Hb}$ was used as the catalyst and the concentration of $\mathrm{Hb}$ greatly influenced the catalytic reaction. On adding more $\mathrm{Hb}$, the peak current increased. Hence, this new electrochemical method can also be used for $\mathrm{Hb}$ detection. Under the selected $\mathrm{Hb}$ catalytic reaction and detection conditions with $2.0 \times 10^{-3} \mathrm{~mol} / \mathrm{l}$ ODA and $4.0 \times 10^{-3} \mathrm{~mol} / 1 \mathrm{H}_{2} \mathrm{O}_{2}$, the second-order derivative linear sweep polarographic peak current also has a good linear relationship with the concentration of free $\mathrm{Hb}$ in the range from $2.0 \times 10^{-9}$ to $3.0 \times 10^{-7} \mathrm{~mol} / \mathrm{l}$ and the linear regression equation is $i p^{\prime \prime}(\mathrm{nA})=14 \cdot 32+3 \cdot 44 \mathrm{C}(\mathrm{nmol} / \mathrm{l})$, $(\gamma=0.997, n=16)$, where $i p^{\prime \prime}(\mathrm{nA})$ is the reductive peak current and $C$ is the concentration of $\mathrm{Hb}$. The relative standard for 11 parallel determination of $2.0 \times 10^{-9} \mathrm{~mol} / \mathrm{l} \mathrm{Hb}$ was $2.95 \%$ and the detection limit was $1.0 \times 10^{-9} \mathrm{~mol} / \mathrm{l}$.

\section{Conclusion}

In this work $\mathrm{Hb}$ was used to catalyse the reduction of hydrogen peroxide, with the subsequent oxidation of $o$-dianisidine (ODA) and the reaction product was reduced at the mercury electrode. Based on the reductive current of the $\mathrm{Hb}$-catalysed reaction product, a new electrochemical method for the determination of microamount of hydrogen peroxide was established and further applied to the determination of the content of $\mathrm{H}_{2} \mathrm{O}_{2}$ in fresh rainwater with satisfactory results.

\section{Acknowledgements}

This work was supported by the National Natural Science Foundation of China and the Natural Science Foundation of Qingdao City.

\section{References}

1. Horvath M 1979 Strahlentherapie 155579

2. Guilbault G G 1970 Enzymatic methods of analysis (Oxford: Pergamon) p. 77

3. Tanner P A and Wong A Y S 1998 Anal. Chim. Acta 370279

4. Xiao Y, Tu H and Chen H 1999 Anal. Chim. Acta 391299

5. Guo Z X, Li L and Shen H X 1999 Anal. Chim. Acta 37963

6. Chen X L, Li D H, Yang H H, Zhu Q Z, Zhen H and Xu J G 2001 Anal. Chim. Acta 43451

7. David S, James C, Robert L T and Gustavo R 1979 Am. J. Clin. Pathol. 72852

8. Blakney G B and Dinweedie A J 1975 Clin. Biochem. 896

9. Zwart A, Baursma A, Van Kampen E J and Zijlstra W G 1984 Clin. Chem. 30373

10. Ye J N and Baldwin R P 1988 Anal. Chem. 602263

11. Zhang Y Z, Zhao H and Yuan Z B 2002 Chem. J. Chin. Univ. 23391

12. Zhang K, Cai R X, Chen D H and Mao L Y 2000 Anal. Chim. Acta 413109

13. Wang Q L, Liu Z H, Cai R X and Lu G X 2002 Chin. J. Anal. Chem. 30928

14. Jiao K, Zhang S S and Wei L 1996 Sci. China B39 135

15. Tijssen P 1985 Practice and theory of enzyme immunoassay (Amsterdam: Elsevier)

16. Jiao $\mathrm{K}$, Zhang S S, Wei L, Liu CF, Zhang C L, Zhang Z F, Liu Y and Wei P 1998 Talanta 47 1129 